"Business characteristics of small and medium enterprises in rural areas: a case study on southern region of KwaZulu-Natal province of South Africa"

AUTHORS

ARTICLE INFO

DOI

RELEASED ON

JOURNAL

FOUNDER
Lawrence Mpele Lekhanya

Lawrence Mpele Lekhanya (2016). Business characteristics of small and medium enterprises in rural areas: a case study on southern region of KwaZulu-Natal province of South Africa. Problems and Perspectives in Management, 14(3), 108114. doi:10.21511/ppm.14(3).2016.11

http://dx.doi.org/10.21511/ppm.14(3).2016.11

Friday, 29 July 2016

"Problems and Perspectives in Management"

LLC "Consulting Publishing Company "Business Perspectives"
NUMBER OF REFERENCES

0

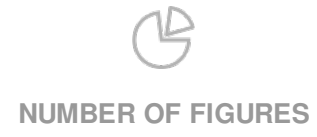

0

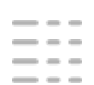

NUMBER OF TABLES

0

(C) The author(s) 2022. This publication is an open access article. 
Lawrence Mpele Lekhanya (South Africa)

\title{
Business characteristics of small and medium enterprises in rural areas: a case study on southern region of KwaZulu-Natal province of South Africa
}

\begin{abstract}
This paper reports on the small and medium enterprises (SMEs) business characteristics in rural places of Southern KwaZulu-Natal (KZN) province. It was intended to identify and discuss the various characteristics and the implications they have on the survival and growth of rural enterprises. The study was conducted in five areas (uMuziwabantu, Ubuhlebezwe, Sisonke, Zingolweni and uMzimkhulu) Southern Region of KZN province. The sample consisted of 127 SMEs owners/managers operating in the selected areas using a quota sampling method, with respondents completing a five-point Likert scale questionnaire with the assistance of an interviewer. The findings indicated that most employees within the business are unskilled; the business operations are run by using modern facilities; most of business investment strategies are hindered by a lack of finance; and the local market is very small in selling rural SMEs' products. SPSS (23.0) version was used for data analysis. The findings presented in the figures and tables. Statistical analysis revealed that business characteristics of SMEs in rural were tested and found to be significant $\left(\mathrm{P}=.000^{*}\right)$.

The paper will be useful tool for the policy-makers, business financial support institutions, and business stakeholders, government policy agencies in underlining a new way to consider future growth of SMEs in rural places, to understand challenges properly and to adjust growth strategies for the remote and under-developed areas. Most work has been focusing on SMEs in the urban and metropolitans areas with less emphasis on the rural SMEs with specific reference to KZN. The findings are limited by the quantitative nature, small sample and exploratory study. Therefore, generalization of these results should be done with care and more research with larger samples extended to other provinces is highly recommended.
\end{abstract}

Keywords: characteristics, rural, small and medium enterprises, Southern KwaZulu-Natal province, business, places. JEL Classification: M31.

\section{Introduction}

Liu and Pang (2015) show that firm survival tends to increase with firm size, and firm growth tends to decrease with firm age, but increase with firm size. However, according to Gupta, Guha and Krishnaswami (2013), four theoretical perspectives, namely, the resource-based perspective, the motivation perspective, the strategic adaptation perspective and the configuration perspective can be identified as enterprise growth. Mugobo and Ukpere (2011) identify issues, such as small market, limited success to finance, shortage and high cost of raw materials, lack of technical and business skills, as well as inaccessible and unreliable communication and transport services, as the most severe constraints characterizing South African rural SMEs. Harvie, Narjoko and Oum (2010) indicate that entrepreneurial attitudes are those important characteristics needed by SMEs to upgrade their positions in production networks. Chittithaworn, Islam, Keawchana and Yusuf (2011) stress that, in other countries, including Thailand, resources and finance, customer and market, as well as the external environment have been recognized as the main characteristics of SMEs that are the most influential factors in business success of SMEs. In India, it has been noticed that the age of the

(C) Lawrence Mpele Lekhanya, 2016.

Lawrence Mpele Lekhanya, Ph.D., Department of Public Management and Economics, Faculty of Management Science, Durban University of Technology, South Africa. entrepreneur, educational level, family background and management style contribute to SME operations and are seen as determinants correlating to the growth of the SME industry (Chachar, De Vita, Parveen and Chachar, 2013). Zarook, Rahman and Khanam (2013) maintain that demographic factors, such as age and size, have a positive, significant impact on SMEs accessing of finance.

\section{Literature review}

1.1. Rural entrepreneurial resources. Harrison and Gibson (2006) show that the inability of small business owners to match their products or services with the demands of the external environment is a major challenge for their strategic growth. SME owners'/managers' level of formal education, access to and use of new technologies and weak management skills also limit the SMEs' survival and growth (Mensah, 2004). Lyons (2002) supports the idea further that SMEs' owners/managers themselves are lacking the necessary skills and capabilities required for business start-up and operations. The Sustainable Agriculture and Rural Development (SARD) policy (2007) draws attention to rural enterprises being characterized by many difficult factors, such as limited resources and because of their small size, scattered nature and remoteness, the transaction costs of rural activities are high, mostly the result of the time required to ensure that standards are met. Rural enterprises face business risks that range from managing the power imbalance they find themselves 
in versus larger firms, to buyers that can influence terms, conditions and standard requirements. In addition, rural enterprises have limited access to timely market information, mainly due to the country's weak transport and communications infrastructure, specifically in rural KZN. SARD policy (2007) states that it is very difficult for rural enterprises to participate in a high value market. Hashi (2001), Peci, Kutllovci, Tmava and Shala (2012), Ghisett, Mazzant, Mancinelli and Zoli (2015) point out that the growth of SMEs has been hampered by a variety of barriers, erected directly or indirectly by the state of the environment. Due to fiscal policy constraints, more specifically, high tax rates, financial constraints in the institutional environment are major barriers for SMEs, which have a huge influence in encouraging many SMEs to conduct their activities in the informal sector of the economy. Beck and Demirque-Kunt (2005) explain that many SMEs are survivalists who need continuation of existence and growth beyond their start-up phase. However, the authors believe that this sector is often faced with difficult challenges, such as market deficiencies and institutional faintness, which hinder their growth. Booyens (2011) offers policy recommendations, stating that the government should encourage the growth of "knowledge networks" that will offer SMEs the opportunity to more easily exchange information with domestic and (especially) large international firms.

1.2. Management skills. A number of common factors within the category of business management are considered to play a role in determining the growth of the small business. These include financial management skills and marketing management skills (Dobbs and Hamilton, 2007; Nkosi, 2013; Kusi, Opata and Narh, 2015). Management skills of small business growth concentrate on the identification of the ownermanager's policies and strategies for the operation and development of their business and the subsequent translation of such policies into managerial action (McMahon, 1998). Penrose (1959) proposes that the growth of the enterprise is limited by the scope of managerial resources, specifically, the ability to coordinate capabilities and introduce new people into the enterprise. Literature reveals considerable doubts regarding the quality of strategic planning and management in this very crucial economic development sector, with policy-makers suggesting particular weaknesses exist in: innovation; a lack of financial acumen; marketing; entrepreneurial flair; practical planning; and management knowledge; as well as human resource management. As a result, many firms do not reach their full potential and fail to grow (Gatukui and Katuse, 2014; Cant and Wiid, 2013). According to Malick and Krishnan (2014), rural markets offer a great scope for a concentrated marketing effort because of the recent increase in rural incomes and the likelihood that such incomes will increase faster because of better production and higher prices for agricultural commodities. Rural marketing is a developing concept, and, as a part of any economy, has untapped potential; marketers have recently realized the opportunity. Improvement in infrastructure and promises rich bright future for those intending to go rural (Ahmed, 2013; Farooqi and Fatma, 2015).

1.3. Technical skills. Entrepreneurial skills assist SMEs to generate growth and development of new ventures in developing economies, such as Kenya, Malysia, South Africa and Nigeria (Mohammed and Obeleagu-Nzelibe, 2014; Situma, Musambayi, Omboto and Yegon, 2015). Robert-Edomi (2013) reports that a recent study conducted in the UK reveals that more than a third ( 36 per cent) of the UK's smaller companies admit to a shortage of skilled staff hindering their growth prospects. Results of the study show that the biggest gap in the small business skillset is in sales, reported by one in six (16 per cent) respondents. A lack of IT (12 per cent) and financial management (ten percent) expertise came in at second and third places, respectively.

1.4. Education and training development. The key word circling around development of economy in many countries is entrepreneurial education (Kalyani and Kumar, 2011). Entrepreneurship education and training has been found to be a major determinant in the growth and survival of enterprises. According to the human capital theory, investment in knowledge, skills and the abilities enhance the productive capacity of the individual (Njoroge and Gathungu, 2013). However, rural small business owners face challenges that are not generally present in urban locations. As a result, they need training programs that are specific to this context (Siemens, 2012). Entrepreneurship education and training entails a philosophy of selfreliance, such as creating a new cultural and productive environment, and promoting new sets of attitudes and culture for the attainment of future challenges (Arogundade, 2011). Economists have maintained that the major obstacle to economic growth of poor nations is the lack of educated entrepreneurs who are able to mobilize and coordinate production inputs (Bawuah, Buame and Hinson, 2006). The inference here is that financial institutions, able to lend funds to uneducated entrepreneurs who lack managerial expertise, are throwing their money away. It is not the financial capital that is lacking, but rather knowledge, ability, and entrepreneurship skills that people possess. In SA, research clearly shows that various problems in schools hinder the effective implementation of entrepreneurship education, some of which are poorly trained 
educators and a lack of adequate resources (Isaacs, Visser, Friedrich and Brijlal, 2007). The authors believe that better entrepreneurship education could make a significant contribution to job creation and, ultimately, to poverty alleviation.

1.5. Infrastructure developments. Aleke, Ojilako and Wainwright (2011) argue that productivity and effectiveness of SMEs in developing countries are affected by the diffusion rate of technology. They believe that availability of state-of-art technology is an important driver for business expansion in rural areas. Mazzarol (2015) stresses that technology should be regarded as an essential part of the business owner-manager's tool box and should not be ignored. He maintains that technology enables small firms to reach millions of people, connect with global supply chains, cost-effectively track customers and enhance internal operations. According to Mbuyisa and Leonard (2015), in South Africa, information and communication technology (ICT) can be used as a tool for driving socio-economic development such as poverty reduction, as well as in the SME environment to an enable growth.

Poor infrastructural facilities such as roads and technology have been mentioned to be major obstacles for SMEs' development and growth (Egbide, Samuel and Samuel, 2013). The South African Rural Development Plan (2013) highlights the need for infrastructure development (e.g., social, economic, information communication technology (ICT), and other enabling infrastructure), enterprise development, small, medium and micro industries (agric-processing, village markets, and finance/credit facilities). These infrastructure developments include high and everincreasing expansions placed on ICT, in terms of bringing about improvement in quality of life, empowerment and economic development for rural communities (Hosman and Fife, 2008). However, Aruwa (2013) points out that it is not economically viable for SMEs to incur infrastructural costs due to the fact that the SMEs are often located away from commercial centres, with a direct negative impact from any infrastructure shortcomings. Consequently, Aruwa argues that inadequacy of infrastructural components, such as electric power supply, transportation, industrial estates and telecommunications, are the major barriers to an effective SMEs' take-off.

\section{Research methodology}

Primary data were collected from small and medium business owners/managers operation in rural areas of the Southern region of KwaZulu-Natal province. Survey questionnaires were distributed to 127 respondents from the selected areas (uMuziwabantu,
Ubuhlebezwe, Sisonke, Zingolweni and uMzimkhulu). Previous literature review was used as the source of information from which to formulate the questionnaire, which was consisted only closed-end. The study used non-probability sampling method, in the form of quota sampling, was used to obtain the desired sample. Quota sampling was used due to time, financial constraints and unavailability of proper list of registered business in the selected areas of survey. The final usable sample is shown in Table 1 in terms of quota control characteristics. A quantitative technique was used to collect primary data. In order to standardize the conditions under which the questionnaires were completed, research assistants from local villages in the selected areas were recruited and trained as fieldworkers. Questionnaires were personally delivered to the target population. The respondents' ability to answer the questionnaire was increased by the provision of a number of instructions throughout the questionnaire, which was personally administered. Data analysis was done by using SPSS (23.0) version and it was reliable at .839 in the Cronbach's Alpha test. The sample quotas were based on three categories of area of the business, number of years of business in operation and how business owned. The profile of the final usable sample was as shown in Table 1.

Table 1. Profile of usable sample as per quota characteristics

\begin{tabular}{|l|c|c|}
\hline & Frequency & Percent \\
\hline Geographic area \\
\hline Harding (uMuziwabantu & 34 & 27 \\
\hline Ixopo (Ubuhlebezwe) & 16 & 13 \\
\hline Underberg (Sisonke) & 19 & 15 \\
\hline Zingolweni & 24 & 19 \\
\hline Umzimkhulu & 34 & 27 \\
\hline Number of years of business in operation & \\
\hline Less than 1 year & 23 & 18 \\
\hline 1-2 years & 39 & 31 \\
\hline 3-5 years & 35 & 28 \\
\hline 6-8 years & 12 & 9 \\
\hline More than 10 years & 18 & 14 \\
\hline How business owned & 41 & 32.3 \\
\hline Partnership & 70 & 55.1 \\
\hline $\begin{array}{l}\text { Manager of the business } \\
\text { and sole owner }\end{array}$ & 16 & 12.6 \\
\hline $\begin{array}{l}\text { Manager of the business } \\
\text { and jointly owned }\end{array}$ & \multicolumn{2}{|l|}{} \\
\hline
\end{tabular}

In this Table number of years of business in operation, was used to determine if their survival was over ten years. Questionnaire was used as a measuring instrument for this survey. The main questions are summarized in Table 2. 
Table 2. Summary of key questions

\begin{tabular}{|l|l|}
\hline \multicolumn{1}{|c|}{$\begin{array}{c}\text { Aspects of business } \\
\text { characteristics in rural places }\end{array}$} & \multicolumn{1}{c|}{ Statement } \\
\hline Skills & $\begin{array}{l}\text { Most employees within the business are } \\
\text { unskilled }\end{array}$ \\
\hline Modern facility & $\begin{array}{l}\text { The business operations are run by using } \\
\text { modern facilities }\end{array}$ \\
\hline Investment & $\begin{array}{l}\text { Most of our business investment strategies } \\
\text { are hindered by a lack of finance }\end{array}$ \\
\hline Local market & $\begin{array}{l}\text { The local market is very small to sell our } \\
\text { business' products }\end{array}$ \\
\hline Infrastructure & $\begin{array}{l}\text { Business operations are largely affected by } \\
\text { poor infrastructure }\end{array}$ \\
\hline
\end{tabular}

\section{Research findings}

Al-Hyani (2013) indicates that the most common constraint hindering SME growth and survival is a lack of qualified human resources. Gandhi and Mohan (2014) echo the sentiment that illiteracy is a serious problem facing South African rural entrepreneurs. In this study, the analysis was done with regard to business skills of rural SMEs to see if this remains a problem in rural SMEs, with specific reference to the KZN areas. Based on the data analysis, the majority of respondents (30 or 24 percent), across industries, strongly agreed and 52 (41 percent) agreed with the statement. There were also 19 (15 percent) of the respondents who were not sure whether they agreed with the statement, while very few of the respondents, 20 (16 percent) disagreed and six (five percent) strongly disagreed. Based on the statement, it is clear that a lack of skills has an impact on the survival and growth of rural SMEs in KZN.

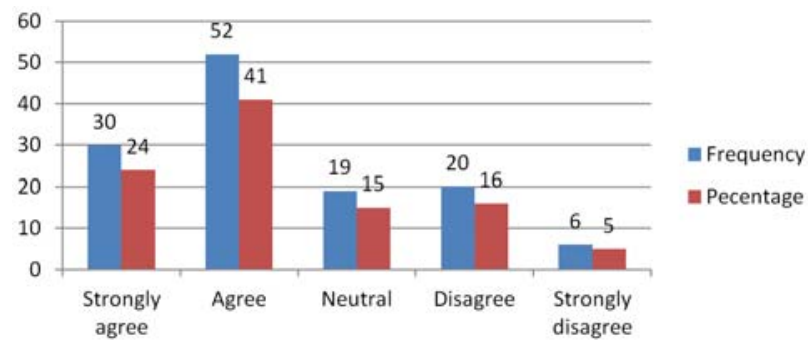

Fig. 1. Unskilled respondents

A Chi-square test was performed, using correlation analysis of the results to determine whether rural entrepreneurship is characterized by unskilled labor. The question was based on the null hypothesis of uniformity of expected responses to questions. The results $\left(\mathrm{X}^{2}=.266 ; \mathrm{df}=1.14644 ; \mathrm{P}=.003\right)$ indicated that the observed findings were significantly different from expected frequencies. In other words, this result was statistically significant and was not due to chance.

6.1. The use of modern facilities. According to Ngorora and Mago (2013), rural entrepreneurship is faced with the challenge of a lack of equipment. Un Nabi and Dornberger (2013, p. 16) maintain that technological capability is widely known as a strategic source of growth and wealth at the national and the firms' levels. Figure 3 illustrate the analysis of the results regarding the use of modern facilities by rural SMEs. The findings show that most respondents, 26 (21 percent) and 58 (46 percent) agree with the statement that modern facilities are used in their businesses. However, 20 (16 percent) of the respondents remained neutral to the statement. The number of respondents who indicated that modern facilities are not used in their businesses were 18 (14 percent) and five (four percent), respectively, disagreeing and strongly disagreeing.

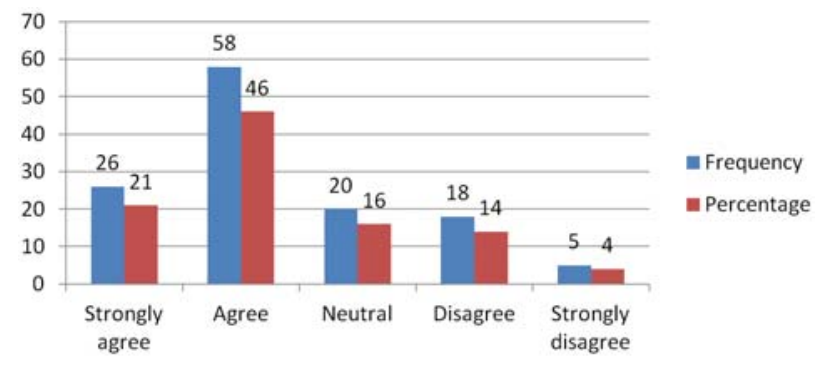

Fig. 2. Use of modern facilities

Using the correlation analysis of the results, a Chisquare test was performed to determine whether modern facilities are used in their businesses. The question was based on the null hypothesis of uniformity of expected responses to questions. The results $\left(\mathrm{X}^{2}=.266 ; \mathrm{df}=1.08033 ; \mathrm{P}=.003\right)$ indicated that the observed findings were significantly different from expected frequencies. In other words, this result was statistically significant and was not due to chance.

6.2. Factors hindering investment strategies. Fakoti and Asah (2011, p. 170) state that, in South Africa, the limiting factor for SME survival and growth is perceived to be the non-availability of debt financing. Zhou and De Wit (2009) support the claim that financial capital is found to be crucial to firm growth. A large proportion of the respondents, 32 (25 percent) and 60 (47 percent) strongly agreed and agreed, respectively, with the statement that most of their business investment strategies are hindered by a lack of finance. While 23 (18 percent) of respondents are neutral, very few of the respondents, nine (seven percent) and three (two percent) disagree and strongly disagreed, respectively.

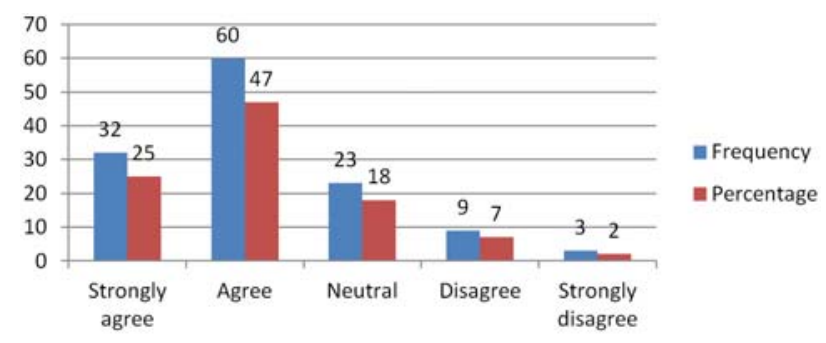

Fig. 3. Factors hindering rural SME investment strategies 
A Chi-square test, using the correlation analysis of the results, was performed to determine whether lack of financial support hindered survival and growth of rural SMEs. The question was based on the null hypothesis of uniformity of expected responses to questions. The results $\left(\mathrm{X}^{2}=.444 ;\right.$ do $\left.=.95721 ; \mathrm{P}=.000\right)$ indicated that the observed findings were significantly different from expected frequencies. In other words, this result was statistically significant and was not due to chance.

6.3. Size of the local market. Khan and Siddiqi (2004, pp. 1-34) indicate that market size has been found to be an important factor affecting a firm's growth. The majority of the respondents, 22 (17 percent) and 57 (45 percent) strongly agreed and agreed, respectively, with the statement that the local market is very small to sell the products of their businesses. From this statement, it is clear that respondents find it very difficult to sell their products in the local market. More than a quarter, 27 (21 percent), of the respondents remained neutral, while less than half of the respondents, 14 (11 percent) and seven (six percent) disagreed and strongly disagreed, respectively, with the statement.

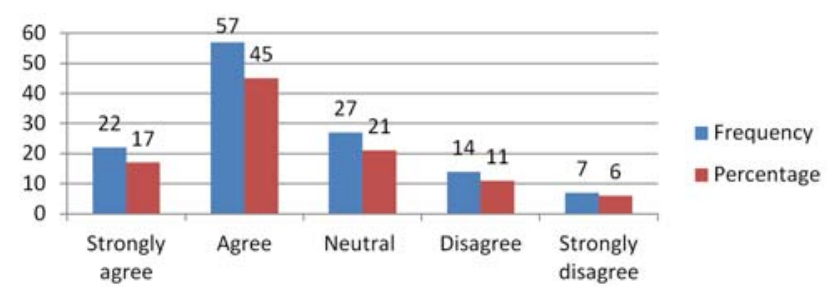

Fig. 4. Size of the local market

Chi-square testing, with the correlation analysis of the results, was performed to determine whether the small size of the local market has an impact on the survival and growth of rural SMEs. The question was based on the null hypothesis of uniformity of expected responses to questions. The results $\left(\mathrm{X}^{2}=.406\right.$; $\mathrm{do}=1.07290 ; \mathrm{P}=.000)$ indicated that the observed findings were significantly different from expected frequencies. In other words, this result was statistically significant and was not due to chance.

6.4. Condition of infrastructure. It has been noticed that condition of infrastructure can also present challenges for the owner and his or her. Standard business infrastructure, including transportation networks, telecommunications, internet and banks, plus social infrastructure such as school and healthcare, may be limited, less developed or nonexistent, as compared with urban (Labrianidis, 2006). The majority of the respondents, 28 ( 22 percent) and 52 (41 percent) strongly agreed and agreed with the statement that poor infrastructure impacts rural SMEs in KZN. While 25 (20 percent) of the respondents remained neutral, 18 (14 percent) and four (three percent) strongly disagreed and agreed, respectively, with the statement.

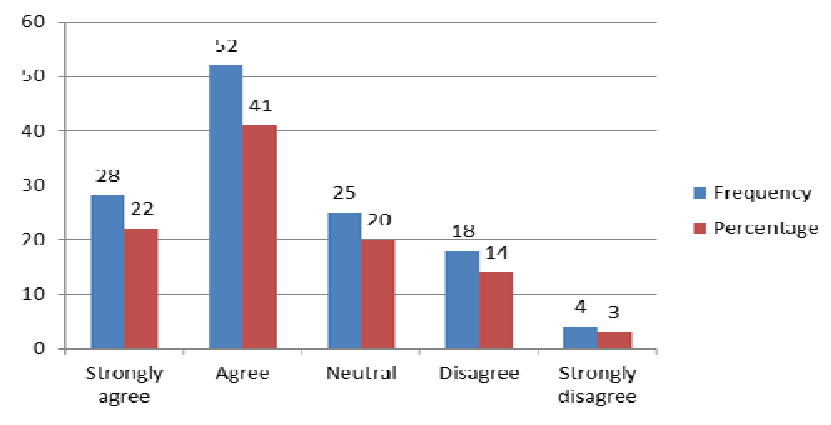

Fig. 5. Condition of infrastructure

\section{Limitations}

Lack of time and willingness by entrepreneurs to complete questionnaires might create problems in obtaining a representative sample. This study was focused only on existing businesses and did not consider proposals for new businesses.

7.1. Implications of the research. The rural SMEs owner/managers, the findings of this study indicate that due to difficulty economic conditions in the South African rural areas with specific reference in KZN, SMEs cannot expand their local market share, as many local customers do not have money and live below economic line. SME also cannot improve in their innovation strategies due to turbulent environment such as poor technology availability in some areas where there is no network or broadband signal. Transport network system in the South Africa rural areas where in some places there are no tire roads or roads are just making by local villagers without any formal engineering skills, therefore, this has negative implications, as affects the distribution of products to the target market in time and also discourage potential new young entrepreneurs.

\section{Conclusions}

Statistically the study establishes that most employees within rural SMEs are unskilled; however, the majority of respondents use modern facilities, including technology. Lack of access to finance was found to be main obstacle for rural SMEs'survival and growth in KZN. The size of the local market was confirmed as another factor affecting rural SMEs' survival and growth in the area, as well as poor infrastructure.

\section{Recommendation}

South African education policy should be improved to include training and development which will assist in increasing the level of entrepreneurial skills transformation in South Africa. This will help SMEs to get skills and knowledge required by business to survive and grow. Many respondents from this study do not have financial skills and business management skills which are perceived to be more critical for many banks to approve loans for SMEs. Therefore, training and education of entrepreneurs in rural areas is essential, as they will learn many basic things such as writing business plan. 


\section{Recommendations for further research}

Further research should assess the use of modern technology as a strategic tool for the improvement of business characteristics typifying rural SMEs,
KZN in particular. This concept will help to expand market size of SMEs by reaching a large customer base. The use of technology will assist in terms of poor infrastructure challenges, such as roads and electricity supply.

\section{Reference}

1. Ahmed, A. (2013). Rural Marketing Strategies for Selling Products \& Services: Issues \& Challenges, Journal of Business Management \& Social Sciences Research, 2 (1), pp. 55-60.

2. Al-Hyar. K. (2013). Identification of Barrier Factors and Potential Solutions to SMEs Development among Jordanian Manufacturing Sector, International Journal of Business and Management, 8 (24), pp. 1-25.

3. Algre, J. and Chiva, R. (2013). Linking Entrepreneurial Orientation and Firm Performance: The Role of Organizational Learning Capability and Innovation Performance, Journal of Small Business Management, 51 (4), pp. 491-507.

4. Aruwa, S. (2013). Correlation between Expenditure on Infrastructural development And Performance of Small and Medium Enterprises in Kaduna State. Available at: http://www.academia.edu/305881/infrastructural_ development_expenditure_and_performance_of_small_and_medium_enterprises_in_kaduna_state. Accessed on $11 / 04 / 2014$.

5. Arogundade, B.B. (2011). Entrepreneurship Education: An Imperative for Sustainable Development in Nigeria, Journal of Emerging Trends in Educational Research and Policy Studies, 2 (1), pp. 26-29.

6. Bawuah, K., Buame, S. and Hinson, R. (2006). Reflections on entrepreneurship education in African tertiary institutions, Acta Commercii, pp. 1-9.

7. Beck, T., Kunt, D.A. and Maksimovic, V. (2006). The Influence of Financial and Legal institutions on firms size, Journal of banking and finance, 30 (11), pp. 2995-3015.

8. Booyens, I. (2011). Are Small, Medium, and Micro-Sized Enterprises Engines of Innovation? The Reality in South Africa, Science and Public Policy, 38 (1), pp. 67-78.

9. Chachar, A.A., De Vita, C.F., Parveen, S., Chachar, Z.A. (2013). The Impact of Cultural Factors on the Growth of Small and Medium Enterprises in Hyderabad, Sindh, International Journal of Science and Research, 2 (1), pp. 83-86.

10. Chitthaworn, C., Islam, A. Md., Keawchana, T., Yusuf, D.H.M. (2011). Factors Affecting Business Success of Small\& Medium Enterprises (SMEs) in Thailand, Asian Social Science, 7 (5), pp. 180-190.

11. Dobbs, M. and Hamilton, R.T. (2007). Small business growth: recent evidence and new directions, International Journal of Entrepreneurial Behavior \& Research, 13 (5), pp. 296-322.

12. Egbide, B., Samuel, F.A. and Samuel, F.O. (2013). Empowering Small and Medium Scale Enterprises in Nigeria: A Key Poverty Alleviation Strategy, International Journal of Business and Management Invention, 2 (5), pp. 6-12.

13. Farooqi, R. and Fatma, G. (2015). Rural Marketing Strategies-Issues \& Challenges in a Developing Economy, Indian Journal of Applied Research, 5 (9), p. 438.

14. Gatukui, P.K. and Katuse, P. (2014). A review of SMEs strategic planning for growth and sustainability in Kenya: issues and challenges, International Journal of Social Sciences and Entrepreneurship, 1 (10), pp. 26-41.

15. Ghisett, C., Mazzant, M., Mancinelli, S. and Zoli, M. (2015). Do financial constraints make the environment worseoff? Understanding the effects of financial barriers on environmental innovations. Available at: http://www.sustainability-seeds.org/papers/RePec/srt/wpaper/0115.pdf. Accessed on 05/12/2015.

16. Gupta, P.D., Guha, S. and Krishnaswami, S.S. (2013). Firm growth and its determinants, Journal of Innovation and Entrepreneurship, 2, pp. 1-15.

17. Harrison, M.L. and Gibson, S.G. (2006). Determining the Common Problems of Early Growth of Small Businesses in Eastern North Carolina, SAM Advanced Management Journal, 71 (2), pp. 39-45.

18. Harvie, C., Narjoko, D. and Oum, S. (2010). Firm Characteristic Determinants of SME Participation in Production Networks. Available at: http://www.eria.org/ERIA-DP-2010-11.pdf. Accessed on 22/05/2014.

19. Hashi, I. (2001). Financial and Institutional Barriers to SME Growth in Albania: Results of an Enterprise Survey, MOCT-MOST, 11 (3), pp. 221-238. Available at: http://dx.doi.org/10.1023/A:1013157127524. Accessed on 11/10/2015.

20. Hosman, L. and Fife, E. (2008). Improving the prospects for sustainable ICT projects in the developing world, International journal of media and cultural politics, 4 (1), pp. 51-69.

21. Isaacs, E., Visser, K., Friedrich, C. and Brijlal, P. (2007). Entrepreneurship education and training at the Further Education and Training (FET) level in South Africa, South African Journal of Education, 27, pp. 613-629.

22. Kalyani, B.P.R. and Kumar, M. (2011). Motivational factors, entrepreneurship and education: Study with reference to women in SMEs, Far East Journal of Psychology and Business, 3 (3), pp. 14-35.

23. Kusi, A., Opata, C.N. and Narh, T.-W.J. (2015). Exploring the Factors That Hinder the Growth andSurvival of Small Businesses in Ghana (A Case Study of Small Businesses within Kumasi Metropolitan Area), American Journal of Industrial and Business Management, 5, pp. 705-723.

24. Liu, J. and Pang, D. (2015). Determinants of survival and growth of Listed SMEs in China. Available at: http://www.researchgate.net/publication/237448798_Determinants_of_survival_and_growth_of_Listed_SMEs_in_ China. Accessed on 23/06/2015. 
25. Lyons, T.S. (2002). Building social capital for rural enterprise development: three case studies in the United States, Journal of Developmental Entrepreneurship, 7 (2), pp. 193-216.

26. Mazzarol, T. (2015). Research review: smes engagement with e-commerce, e-business and e-marketing, Small enterprise research, 22 (1), pp. 79-90.

27. Mbuyisa, B. and Leonard, A. (2015). ICT adoption in SMEs for the alleviation of poverty, International Association for Management of Technology, IAMOT 2015 Conference Proceedings. Available at: http://www.iamot2015.com/2015proceedings/documents/P105.pdf. Accessed on 15/12/2015.

28. McMahon, R.G.P. (1998). Stage models of SME growth reconsidered, Small Business Research: The Journal of SEAANZ, 6 (2), pp. 20-35.

29. Mensah, S. (2004). A Review of SME Financing Schemes in Ghana. UNIDO Regional Workshop of Financing Small and Medium Scale Enterprises, Accra-Ghana, 15-16 March.

30. Mohammed, U.D. and Obeleagu-Nzelibe, C.G. (2014). Entrepreneurial Skills and Profitability of Small and Medium Enterprises (SMEs): Resource Acquisition Strategies for New Ventures in Nigeria. Proceedings of 25th International Business Research Conference 13-14 January, 2014, Taj Hotel, Cape Town, South Africa.

31. Mugobo, V.V. and Ukpere, W. (2012). Rural entrepreneurship in the Western Cape: Challenges and opportunities, African Journal of Business Management, 6 (3), pp. 827-836.

32. Ngorora, G.P.K. and Mago, S. (2013). Challenges of rural entrepreneurship in South Africa: insights from nkonkobe municipal area in the Eastern Cape Province, International Journal of Information Technology and Business Management, 16 (1), pp. 1-11.

33. Njoroge, C.W. and Gathungu, J.M. (2013). The effect of entrepreneurial education and training on development of small and medium size enterprises in Githunguri district - Kenya, International Journal of Education and Research, 1 (8), pp. 1-22.

34. Nkosi, E. (2013). Skills required for the management of Black-owned small enterprises in Soweto, Independent research journal in the management sciences, 13 (1), pp. 1-8.

35. Peci, F., Kutllovci, E., Tmava, Q. and Shala, V. (2012). Small and Medium Enterprises Facing InstitutionalBarriers in Kosovo, International Journal of Marketing Studies, 4 (1), pp. 1-13.

36. Penrose, E. (1959). The theory of the growth of the firm. Oxford: Oxford University Press.

37. Robert-Edomi, S. (2013). Skills gap hindering SME growth, study finds. Available at: https://www.trainingjournal.com/articles/news/skills-gap-hindering-sme-growth-study-finds. Accessed on 06/09/2014.

38. Siemens. L. (2012). Embeddling small business and entrepreneurship training within the rural context, Entrepreneurship and innovation, 13 (3), pp. 165-178.

39. Situma, C.M.K., Musambayi, N.J., Omboto, P.I. and Yegon, E. (2015). Critical analysis of entrepeneurship education on SMEs development in Kenya, The International Journal of Business \& Management, 3 (1), pp. 332-338.

40. The Sustainable Agricultural Rural Development (SARD) policy. (2007). The Sustainable Agricultural Rural Development (SARD) Initiative Report on the period 2002-2008. Available at: https://sustainabledevelopment.un.org/content/sustdev/csd/csd16/PF/presentations/sard.pdf. Accessed on 05/12/2015.

41. Zarook, T., Rahman, M.M. and Khanam, R. (2013). Management Skills and Accessing to Finance: Evidence from Libya's SMEs, International Journal of Business and Social Science, 4 (7), pp. 106-115. 